\title{
Comparison of Serum CA 19.9, CA 125 and CEA Levels with Severity of Chronic Obstructive Pulmonary Disease
}

\author{
I. Bulut ${ }^{a} \quad$ P. Arbak ${ }^{b} \quad$ A. Coskun ${ }^{b} \quad$ O. Balbay ${ }^{b} \quad$ A.N. Annakkaya ${ }^{b} \quad$ O. Yavuz ${ }^{b}$ \\ E. Gülcan ${ }^{a}$ \\ a School of Medicine, Dumlupinar University, Kütahya, and ' ${ }^{b}$ Duzce School of Medicine, Duzce University, \\ Duzce, Turkey
}

\section{Key Words}

Chronic obstructive pulmonary disease - Tumor markers •

Cor pulmonale

\begin{abstract}
Objective: To investigate serum levels of CA 19.9, CA 125 and carcinoembryonic antigen (CEA) in patients with different stages of chronic obstructive pulmonary disease (COPD). Patients and Methods: Fifty-three consecutive patients (50 males, 3 females, mean age $67.6 \pm 10.1$ years) with COPD were included in this study. Serum levels of CA 19.9, CA 25 and CEA were determined by the chemiluminescent immunometric method. Based on values obtained from pulmonary function tests, the patients were divided into 3 groups: moderate (21), severe (18) and very severe (14). Data were analyzed with a Kruskal-Wallis one-way analysis of variance test and Mann-Whitney U test. Results: The mean serum levels of CA 125 and CA 19.9 were significantly higher in patients with very severe COPD $(p=0.013$ and $p=0.017$, respectively) than in patients with severe and moderate COPD $(p<0.05)$. Patients with cor pulmonale had significantly high mean serum levels of CEA, CA 19.9 and CA 125 ( $p<0.05)$. Patients using a long-acting $\beta$-agonist and theophylline showed significantly higher mean serum levels of CA 125 than patients who were not $(p<0.05)$. Conclusion: Data showed that the
\end{abstract}

increased serum tumor markers in patients with COPD might be due to the severity of COPD, medication and cor pulmonale.

Copyright $\odot 2009$ S. Karger AG, Basel

\section{Introduction}

Although serum tumor markers were introduced in clinical use as biochemicals for monitoring response to therapy and detecting early relapse in malignancies, it has been observed that increased levels of these tumor markers can also be detected in benign conditions. Carcinoembryonic antigen (CEA), an oncofetal glycoprotein expressed in normal mucosal cells and overexpressed in colorectal adenocarcinoma, has been shown to be increased in subjects who have a peptic ulcer, inflammatory bowel disease, pancreatitis, hypothyroidism, biliary obstruction, cirrhosis and/or who smoke cigarettes [1,2]. It has also been shown that CEA concentrations are more frequently elevated in men than in women [3-5] and that older patients have higher CEA concentrations than younger ones [6]. Elevated levels of CA 125, a glycoprotein normally expressed in coelomic epithelium during fetal development, is most often associated with epithelial ovarian cancer, but has also been observed in endo- 
Table 1. The demographical, clinical and diagnostic characteristics of COPD patients and type of treatment

\begin{tabular}{|c|c|}
\hline & Number of patients \\
\hline \multicolumn{2}{|l|}{ Gender } \\
\hline Male & $50(94.3)$ \\
\hline Female & $3(5.7)$ \\
\hline \multicolumn{2}{|l|}{ Smoking } \\
\hline No & $48(90.6)$ \\
\hline Yes & $5(9.4)$ \\
\hline \multicolumn{2}{|l|}{ COPD severity } \\
\hline Moderate & $21(39.6)$ \\
\hline Severe & $18(34.0)$ \\
\hline Very severe & $14(26.4)$ \\
\hline \multicolumn{2}{|l|}{ Hypoxemia } \\
\hline No & $16(30.2)$ \\
\hline Yes & $37(69.8)$ \\
\hline \multicolumn{2}{|l|}{ Cor pulmonale } \\
\hline No & $28(52.8)$ \\
\hline Yes & $25(47.2)$ \\
\hline \multicolumn{2}{|c|}{ Concomitant disease ${ }^{1}$} \\
\hline No & $36(67.9)$ \\
\hline Yes & $17(32.1)$ \\
\hline \multicolumn{2}{|c|}{ Short-acting $\beta$-agonist } \\
\hline No & $13(24.5)$ \\
\hline Yes & $40(75.5)$ \\
\hline \multicolumn{2}{|c|}{ Long-acting $\beta$-agonist } \\
\hline No & $12(22.6)$ \\
\hline Yes & $41(77.4)$ \\
\hline \multicolumn{2}{|l|}{ Anticholinergic } \\
\hline Yes & $53(100.0)$ \\
\hline \multicolumn{2}{|l|}{ Theophylline } \\
\hline No & $9(17.0)$ \\
\hline Yes & $44(83.0)$ \\
\hline \multicolumn{2}{|c|}{ Steroid + long-acting $\beta$-agonist (inhaler) } \\
\hline No & $48(90.6)$ \\
\hline Yes & $5(9.4)$ \\
\hline \multicolumn{2}{|c|}{ Steroid (inhaler) } \\
\hline No & $45(84.9)$ \\
\hline Yes & $8(15.1)$ \\
\hline \multicolumn{2}{|l|}{ Steroid (oral) } \\
\hline No & $52(98.1)$ \\
\hline Yes & $1(1.9)$ \\
\hline
\end{tabular}

Values in parentheses are percentages.

${ }^{1}$ History of hypertension, diabetes mellitus and inactive tuberculosis.

metriosis, ovarian cysts, pleuritis, alcoholic hepatitis and the first trimester of normal pregnancy [7]. CA 19.9 is an intracellular adhesion molecule, occurring primarily in patients with pancreatic and biliary tract cancers, but has also been reported in patients with benign conditions such as cirrhosis, cholestasis and pancreatitis [8].
It has been shown in several studies $[9,10]$ that the serum levels of various tumor markers in nonneoplastic diseases of the lung can also be associated with increased levels of different tumor markers, as shown by the striking increase in CA 125 in cases of acute bronchopneumonia [9] and CEA levels in patients with pneumonia and chronic obstructive pulmonary disease (COPD) [10].

Previous studies regarding the diagnostic value of various tumor markers in cases of lung cancer included patients with benign pulmonary diseases, such as COPD, pneumonia, pneumoconiosis and tuberculosis, as controls [10-13]. Generally, serum levels of CEA were higher in lung cancer than those of benign pulmonary diseases, including COPD [11-13]. However, Sanguinetti et al. [10] have shown that the mean serum CEA value in peripheral lung cancer patients did not differ from that in nonneoplastic and healthy subjects. In another study, the mean bronchial lavage fluid level of CEA in patients with lung cancer, pneumonia and COPD was significantly increased compared to healthy subjects, whereas there was no statistically significant difference in the bronchial lavage fluid level of CEA among these 3 groups of patients [10]. In these studies, the spirometric values, measurements of arterial blood gas analysis and the severity of the patients' COPD were not evaluated. As a result, further studies including patients with COPD were thought to be necessary. Hence, the objective of this study was to investigate the serum levels of CEA, CA 19.9 and CA 125 in patients with different stages of COPD. Additionally, we evaluated the serum levels of these tumor markers according to the presence of hypoxemia, cor pulmonale and the usage of various medications for COPD.

\section{Patients and Methods}

\section{Patients}

Fifty-three consecutive patients (50 males, 3 females; mean age $67.6 \pm 10.1$ years) with COPD were included in this study. A history of disease, physical examination, spirometric values, arterial blood gas values, electrocardiograms (echocardiography when necessary) and chest radiograms were obtained from all patients. Patients with known cancers (lung, colorectal adenocarcinoma, ovarian, pancreatic and biliary tract) were excluded. The 53 patients received a drug regimen commensurate with the severity of COPD. Informed consent for the study was obtained from all patients. The demographical, clinical and diagnostic characteristics of COPD patients and the type of treatment are shown in table 1.

Pulmonary functions were measured by a spirometer (Vitalograph Alpha; Vitalograph Ltd., Ennis, Ireland). The forced expiratory volume in $1 \mathrm{~s}\left(\mathrm{FEV}_{1}\right)$, the forced vital capacity $(\mathrm{FVC})$ and 
Table 2. Comparison of age, smoking habits, spirometric measurements and arterial blood gas analysis of patients with different severities of COPD

\begin{tabular}{lcccc}
\hline \multicolumn{2}{l}{ COPD severity } & & & \\
\cline { 2 - 5 } & $\begin{array}{l}\text { moderate } \\
\mathrm{n}=21\end{array}$ & $\begin{array}{l}\text { severe } \\
\mathrm{n}=18\end{array}$ & $\begin{array}{l}\text { very severe } \\
\mathrm{n}=14\end{array}$ & $\mathrm{p}$ \\
\hline Age, years & $66.4 \pm 9.6$ & $68.4 \pm 9.3$ & $68.4 \pm 12.3$ & $\mathrm{NS}$ \\
Diagnosis duration, years & $4.4 \pm 4.3$ & $7.4 \pm 4.6$ & $7.9 \pm 7.6$ & $\mathrm{NS}$ \\
Smoking duration, years & $37.2 \pm 9.9$ & $40.2 \pm 10.9$ & $38.9 \pm 12.4$ & $\mathrm{NS}$ \\
Smoking, pack-years & $55.5 \pm 32.2$ & $49.7 \pm 16.4$ & $61.7 \pm 37.5$ & $\mathrm{NS}$ \\
FEV $/$ FVC & $62.33 \pm 7.4$ & $53.61 \pm 11.4$ & $44.90 \pm 14.1$ & 0.000 \\
$\mathrm{FEV}_{1}, \%$ predicted & $63.19 \pm 7.9$ & $39.00 \pm 6.6$ & $25.56 \pm 3.8$ & 0.000 \\
$\mathrm{PO}_{2}$ & $79.85 \pm 16.0$ & $65.57 \pm 21.6$ & $57.49 \pm 17.3$ & 0.005 \\
$\mathrm{PCO}_{2}$ & $43.09 \pm 5.9$ & $47.26 \pm 10.4$ & $52.89 \pm 9.0$ & 0.009 \\
$\mathrm{CA} 125_{\mathrm{CA} 19.9}$ & $10.30 \pm 19.9$ & $15.58 \pm 18.9$ & $36.08 \pm 71.4$ & 0.013 \\
$\mathrm{CEA}$ & $7.48 \pm 8.2$ & $9.44 \pm 9.3$ & $19.23 \pm 13.1$ & 0.017 \\
\hline
\end{tabular}

Differences among groups were determined by means of Kruskal-Wallis one-way analysis of variance test; p value $<0.05$ was considered as significant. NS $=$ Nonsignificant.

the ratio of forced expiratory volume in $1 \mathrm{~s}$ to forced vital capacity $\left(\mathrm{FEV}_{1} / \mathrm{FVC}\right)$ were recorded. The maximum volumes obtained were taken into account. Predicted volumes were obtained from standard nomograms for comparison.

Patients were grouped into moderate, severe and very severe COPD, based on the classification of the severity of COPD set forth in the report by the Global Initiative for Chronic Obstructive Lung Disease [14]. Moderate COPD patients were those with a predicted $\mathrm{FEV}_{1} / \mathrm{FVC}<70 \%$ and a predicted $\mathrm{FEV}_{1} \geq 50-80 \%$. Severe COPD patients had a predicted $\mathrm{FEV}_{1} / \mathrm{FVC}<70 \%$ and a predicted $F E V_{1} \geq 30-50 \%$. Very severe COPD patients had a predicted $\mathrm{FEV}_{1} / \mathrm{FVC}<70 \%$ and a predicted $\mathrm{FEV}_{1} \leq 30 \%$, or a predicted $\mathrm{FEV}_{1}<50 \%$ plus chronic respiratory failure. Hence, the number of moderate, severe and very severe COPD patients amounted to 21, 18 and 14, respectively. There were no patients with either mild COPD or only a risk of COPD. Arterial blood gas tensions $\left(\mathrm{PaO}_{2}, \mathrm{PaCO}_{2}\right)$ and $\mathrm{pH}$ were measured by an arterial blood gas analyzer (I-Stat Corp., East Windsor, N.J., USA).

\section{Measurement of Tumor Markers}

Blood samples were collected from each patient when they visited the Department of Chest Diseases for their follow-up. All blood samples were immediately centrifuged for $10 \mathrm{~min}$ at $1,500 \mathrm{~g}$ and sera were stored at $-40^{\circ} \mathrm{C}$ until analysis. All samples were processed within 1 month of collection. Serum CA 125, CA 19.9 and CEA concentrations were determined by the chemiluminescent immunometric method in each group using Immulite (Euro/DPC Ltd., Llanberis, UK). The serum reference range of CA 125 and CA 19.9 is $2.6-18$ and $0-33 \mathrm{U} / \mathrm{ml}$, respectively. For CEA, the reference ranges for smokers and nonsmokers are $0.42-$ 6.3 and $0.21-3.3 \mathrm{U} / \mathrm{ml}$, respectively.

\section{Statistical Analysis}

Differences between 2 or more groups were determined by means of a Kruskal-Wallis one-way analysis of variance test; dif- ferences between 2 independent groups were determined by means of a Mann-Whitney $U$ test. A value of $p<0.05$ was considered significant and all analyses were performed by using a statistical package (SPSS-10.0 for Windows).

\section{Results}

The mean age, diagnosis duration of COPD, smoking duration, smoking by means of pack-years, $\mathrm{FEV}_{1} / \mathrm{FVC}$, $\mathrm{FEV}_{1}, \mathrm{PO}_{2}, \mathrm{PCO}_{2}$ and serum levels of CA 125, CA 19.9 and CEA of the patients are shown in table 2. The mean serum level of CA 125 was significantly higher in patients with very severe COPD $(36.08 \pm 71.40)$ than in patients with severe COPD or moderate COPD (15.58 \pm 18.90 and $10.30 \pm 19.99$, respectively; $\mathrm{p}=0.013)$. Patients with very severe COPD also had significantly higher levels of CA 19.9 (19.23 \pm 13.15$)$ than those with severe COPD or moderate COPD (9.44 \pm 9.34 and $7.48 \pm 8.26$, respectively; $\mathrm{p}=0.017)$. No significant difference was found among the subgroups of patients with COPD according to the mean serum levels of CEA ( $p>0.05)$. During the study period, we systematically checked for diseases of the gastrointestinal tract and gynecological system in all patients with increased tumor markers above the upper reference value. The percentages of false-positive values for CA 125 , CA 19.9 and CEA were 18.8, 3.7 and 9.4\%, respectively. The highest false-positive values for CA 125, CA 19.9 and CEA were observed in patients with very severe COPD. 
Table 3. Mean serum levels of markers related to presence of hypoxemia, cor pulmonale and type of medication

\begin{tabular}{|c|c|c|c|c|c|c|}
\hline & CEA & $\mathrm{p}$ & CA 19.9 & $\mathrm{p}$ & CA 125 & $\mathrm{p}$ \\
\hline \multicolumn{7}{|c|}{ Hypoxemia } \\
\hline Yes & $3.5 \pm 2.0$ & \multirow[t]{2}{*}{ NS } & $12.6 \pm 12.4$ & \multirow[t]{2}{*}{ NS } & $20.6 \pm 46.4$ & \multirow[t]{2}{*}{ NS } \\
\hline No & $3.7 \pm 3.9$ & & $7.9 \pm 5.9$ & & $15.6 \pm 26.1$ & \\
\hline \multicolumn{7}{|c|}{ Cor pulmonale } \\
\hline Yes & $3.9 \pm 1.9$ & \multirow[t]{2}{*}{0.030} & $15.7 \pm 12.9$ & \multirow[t]{2}{*}{0.023} & $28.5 \pm 56.9$ & \multirow[t]{2}{*}{0.004} \\
\hline No & $3.2 \pm 3.2$ & & $7.2 \pm 7.1$ & & $11.3 \pm 19.6$ & \\
\hline \multicolumn{7}{|c|}{ Short-acting $\beta$-agonist } \\
\hline Yes & $3.7 \pm 2.9$ & NS & $12.6 \pm 12.0$ & \multirow[t]{2}{*}{ NS } & $21.7 \pm 46.6$ & \multirow[t]{2}{*}{ NS } \\
\hline No & $3.1 \pm 1.8$ & & $7.0 \pm 5.7$ & & $11.3 \pm 17.4$ & \\
\hline \multicolumn{7}{|c|}{ Long-acting $\beta$-agonist } \\
\hline Yes & $3.6 \pm 2.6$ & NS & $12.1 \pm 11.8$ & \multirow[t]{2}{*}{ NS } & $22.8 \pm 46.6$ & \multirow[t]{2}{*}{0.035} \\
\hline No & $3.2 \pm 2.9$ & & $8.1 \pm 7.4$ & & $6.9 \pm 7.0$ & \\
\hline \multicolumn{7}{|c|}{ Theophylline } \\
\hline Yes & $3.6 \pm 2.7$ & \multirow[t]{2}{*}{ NS } & $12.4 \pm 11.6$ & \multirow[t]{2}{*}{ NS } & $20.2 \pm 43.5$ & \multirow[t]{2}{*}{0.035} \\
\hline No & $3.4 \pm 2.8$ & & $5.5 \pm 4.5$ & & $14.0 \pm 30.1$ & \\
\hline \multicolumn{7}{|c|}{ Steroid (inhaler) } \\
\hline Yes & $3.9 \pm 3.2$ & \multirow[t]{2}{*}{ NS } & $15.8 \pm 12.3$ & \multirow[t]{2}{*}{ NS } & $29.5 \pm 32.5$ & \multirow[t]{2}{*}{ NS } \\
\hline No & $3.5 \pm 2.6$ & & $10.4 \pm 10.7$ & & $17.2 \pm 42.8$ & \\
\hline \multicolumn{7}{|c|}{ Long-acting $\beta$-agonist + steroid (inhaler) } \\
\hline Yes & $2.7 \pm 2.6$ & \multirow[t]{2}{*}{ NS } & $4.9 \pm 2.8$ & \multirow[t]{2}{*}{ NS } & $8.3 \pm 4.5$ & \multirow[t]{2}{*}{ NS } \\
\hline No & $3.6 \pm 2.7$ & & $11.9 \pm 11.3$ & & $20.3 \pm 43.3$ & \\
\hline
\end{tabular}

Differences between two independent groups were determined by means of Mann-Whitney U test; $p$ value $<0.05$ was considered significant. NS = Nonsignificant.

The mean serum levels of tumor markers according to the presence of hypoxemia, cor pulmonale, usage of inhaler short-acting $\beta$-agonist, inhaler long-acting $\beta$-agonist, theophylline (peroral), steroid (inhaler) and longacting $\beta$-agonist + steroid (inhaler) are shown in table 3 .

Patients with cor pulmonale compared to patients without cor pulmonale had significantly higher mean serum levels of CEA $(3.95 \pm 1.97$ vs. $3.25 \pm 3.22, \mathrm{p}=0.030)$, CA $19.9(15.72 \pm 12.96$ vs. $7.26 \pm 7.12, \mathrm{p}=0.023)$ and CA $125(28.57 \pm 56.92$ vs. $11.39 \pm 19.60, \mathrm{p}=0.004)$. Patients using long-acting $\beta$-agonist showed significantly higher mean serum levels of CA 125 than patients who were not $(22.88 \pm 46.60$ vs. $6.98 \pm 7.07, \mathrm{p}=0.035)$. There were no significant differences in the serum levels of CA 19.9 and CEA according to the usage of long-acting $\beta$-agonist. Theophylline users had higher mean serum levels of CA 125 than patients who were not using theophylline (20.22 \pm 43.57 vs. $14.09 \pm 30.11, \mathrm{p}=0.035)$. No significant differences were found in the serum levels of CA 19.9 and CEA related to the usage of theophylline. The mean serum levels of CEA, CA 19.9 and CA 125 did not differ ac- cording to the presence of hypoxemia, usage of short-acting $\beta$-agonist, steroid (inhaler) or long-acting $\beta$-agonist + steroid (inhaler).

\section{Discussion}

The present study demonstrated that CA 19.9 and CA 125 increased in relation to the severity of COPD, and these were accordingly highest in patients with very severe COPD. Equally important, the presence of cor pulmonale was associated with significantly high mean serum levels of CEA, CA 19.9 and CA 12, and increased mean levels of CA 125 were observed in patients using long-acting $\beta$-agonist and theophylline.

Our data confirmed the previous results $[15,16]$ of increased mean serum levels of CEA in cigarette smokers with no known carcinoma. In a reference range study of more than 700 individuals from 4 European countries, the 95th percentile upper limits of the CEA assay for male smokers and nonsmokers were 6.2 and $3.4 \mu \mathrm{g} / \mathrm{l}$, respectively, and for female smokers and nonsmokers, 4.9 and $2.5 \mu \mathrm{g} / \mathrm{l}$, respectively [17]. No false-positive values for serum levels of CA 125 and CA 19.9 were reported by Green et al. [18]. However, significantly higher false-positive CA 125 values in patients with COPD were observed in our study. Although most of the patients were ex-smoker COPD patients, false-positive values in CEA were compatible with previous studies. Increased false-positive CEA values in ex-smoker COPD patients might be due to the permanent effect of smoking at the cellular level.

In the present study, no significant differences were found among the 3 groups of patients with COPD in regard to smoking duration or smoking consumption in pack-years. However, one could expect to find the serum levels of CA 19.9 and CA 125, as well as the serum level of CEA, to be elevated significantly in patients with very severe COPD. Based on our data, we speculated that there must be some explanations other than smoking cigarettes for the association between very severe COPD and elevated mean serum levels of CA 19.9 and CA 125.

COPD is defined as an incompletely reversible airflow limitation associated with inflammation, in which monocytes and macrophages are the predominant inflammatory cells [19]. Various inflammatory mediators derived from these inflammatory cells are suggested to contribute to the chronic inflammation and cause lung tissue damage [20]. Alveolar-macrophage-derived metalloproteinases mediate inflammation by releasing tumor necrosis factor- $\alpha$ from macrophages with subsequent neu- 
trophil influx, endothelial activation and tissue breakdown caused by neutrophil-derived proteinases [21]. A study by Aldonyte et al. [22] showed that monocytes isolated from patients with stable COPD release more matrix metallopeptidase (MMP)-9, thereby favoring the theory that supports the potential role of high levels of MMP (including MMP-9) in amplifying inflammation in COPD. MMP-9 has also been shown to be markedly overexpressed by alveolar macrophages in patients with COPD in another study [23]. It has been reported that matrix metalloproteinase inhibitors decreased the serum levels of CEA, CA 19.9, CA 125 and prostate-specific antigen in follow-ups of patients with colorectal, ovarian, pancreatic and prostate cancer [24].

It is well known that hepatic diseases can reduce the metabolism of different tumor markers [15]. Hence, the rise of CEA, CA 19.9 and CA 125 in association with cor pulmonale could be expected due to hepatic stasis, as ob- served in this study. Additionally, there may be some other mechanisms, such as increased atrial natriuretic factor, which might be responsible for increased serum tumor markers.

The increase in CA 125 levels in patients using theophylline or long-acting $\beta_{2}$-mimetics might be due to interaction at the level of excretion, secretion and degradation metabolism in the liver.

The limitations of our study are the absence of patients with mild COPD or only a low risk of COPD, as well as the small sample size.

\section{Conclusion}

Data showed that increased serum tumor markers in patients with COPD might be due to the severity of COPD medications and the presence of cor pulmonale.

\section{References}

1 Fletcher RH: Carcinoembryonic antigen. Ann Intern Med 1996;104:66-73.

-2 Perkins GL, Slater ED, Sanders GK, Prichard JG: Serum tumor markers. Am Fam Physician 2003;68:1075-1082.

-3 Stockley RA, Shaw J, Whitfield AG, Whitehead TP, Clarke CA, Burnett D: Effect of cigarette smoking, pulmonary inflammation, and lung disease on concentrations of carcinoembryonic antigen in serum and secretions. Thorax 1986;41:17-24.

4 Stevens DP, Mackay IR: Increased carcinoembryonic antigens in heavy smokers. Lancet 1973;ii:1238-1239.

5 Beaudonnet A, Gounon G, Pichot J, Revenant MC: Sex- and age-related influences on carcinoembryonic antigen in blood. Clin Chem 1981;27:771.

-6 Touitou Y, Proust J, Klinger E, Nakache JP, Huard D, Sachet A: Cumulative effects of age and pathology on plasma carcinoembryonic antigen in an unselected elderly population. Eur J Cancer Clin Oncol 1984;20:369-374.

>7 Bast RC Jr, Xu FJ, Yu YH, Barnhill S, Zhang Z, Mills GB: CA 125: the past and the future. Int J Biol Markers 1998;13:179-187.

-8 Steinberg W: The clinical utility of the CA 19-9 tumor-associated antigen. Am J Gastroenterol 1990;85:350-355.

-9 Marechal F, Berthiot G, Deltour G: Serum levels of CA-50, CA-19.9, CA-125, CA-15.3, enolase and carcino-embryonic antigen in non-neoplastic diseases of the lung. Anticancer Res 1988;8:677-680.

-10 Sanguinetti CM, Riccioni G, Marchesani F, Pela R, Cecarini L: Bronchoalveolar lavage fluid level of carcinoembryonic antigen in the diagnosis of peripheral lung cancer. Monaldi Arch Chest Dis 1995;50:177-182.

11 Schneider J, Bitterlich N, Velcovsky HG, Morr H, Katz N, Eigenbrodt E: Fuzzy logicbased tumor marker profiles improved sensitivity in the diagnosis of lung cancer. Int J Clin Oncol 2002;7:145-151.

12 Macchia V, Mariano A, Cavalcanti M, Coppa A, Cecere C, Fraioli G, et al: Tumor markers and lung cancer: correlation between serum and bronchial secretion levels of CEA, TPA, CanAg CA-50, NSE and ferritin. Int J Biol Markers 1987;2:151-156.

-13 Niklinski J, Chyczewska E, Furman M, Kowal E, Laudanski J, Chyczewski L: Usefulness of a multiple biomarker assay in bronchoalveolar lavage (BAL) and serum for the diagnosis of small cell lung cancer. Neoplasma 1993;40:305-308.

14 Gomez FP, Rodriguez-Roisin R: Global Initiative for Chronic Obstructive Lung Disease (GOLD) guidelines for chronic obstructive pulmonary disease. Curr Opin Pulm Med 2002;8:81-86.

15 Torosian MH: The clinical usefulness and limitations of tumor markers. Surg Gynecol Obstet 1988;166:567-579.

16 Cullen KJ, Stevens DP, Frost MA, Mackay IR: Carcinoembryonic antigen (CEA), smoking, and cancer in a longitudinal population study. Aust NZ J Med 1976;6:279-283.

17 Wilson AP, Van Dalen A, Sibley PE, Kasper LA, Durham AP, el Shami AS: Multicentre tumour marker reference range study. Anticancer Res 1999;19:2749-2752.

18 Green PJ, Ballas SK, Westkaemper P, Schwartz HG, Klug TL, Zurawski VR: CA
19-9 and CA 125 levels in the sera of normal blood donors in relation to smoking history. J Natl Cancer Inst 1986;77:337-341.

19 Corrigan CJ, Kay AB: The roles of inflammatory cells in the pathogenesis of asthma and of chronic obstructive pulmonary disease. Am Rev Respir Dis 1991;143:1165-1168.

20 Chung KF: Cytokines in chronic obstructive pulmonary disease. Eur Respir J Suppl 2001; 34:50-59.

21 Maus U, Huwe J, Ermert L, Ermert M, Seeger W, Lohmeyer J: Molecular pathways of monocyte emigration into the alveolar air space of intact mice. Am J Respir Crit Care Med 2002;165:95-100.

22 Aldonyte R, Jansson L, Piitulainen E, Janciauskiene S: Circulating monocytes from healthy individuals and COPD patients. Respir Res 2003;4:11.

23 Russell RE, Thorley A, Culpitt SV, Dodd S, Donnelly LE, Demattos C, Fitzgerald M: Barnes, PJ: Alveolar macrophage-mediated elastolysis: roles of matrix metalloproteinases, cysteine, and serine proteases. Am J Physiol Lung Cell Mol Physiol 2002;283: 867-873.

24 Nemunaitis J, Poole C, Primrose J, Rosemurgy A, Malfetano J, Brown P, Berrington A, Cornish A, Lynch K, Rasmussen H, Kerr D, Cox D, Millar A: Combined analysis of studies of the effects of the matrix metalloproteinase inhibitor marimastat on serum tumor markers in advanced cancer: selection of a biologically active and tolerable dose for longer-term studies. Clin Cancer Res 1998;4: 1101-1109. 